\title{
IMPLEMENTATION OF A SERVICE LEARNING METHODOLOGY TO INCREASE MOTIVATION AND REDUCE SCHOOL DROPOUT IN HIGH SCHOOL STUDENTS
}

\author{
S. Blanco, M. B. Muñoz, M. G. Alberti, A. Enfedaque, M. Romana, A. L. Lara \\ Universidad Politécnica de Madrid (U.P.M.) (SPAIN) \\ sergio.blanco@upm.es,mariabelen.munoz@upm.es,marcos.garcia@upm.es, \\ alejandro.enfedaque@upm.es, manuel.romana@upm.es, antoniolorenzo.lara@upm.es
}

\begin{abstract}
In this work, an experience of service learning carried out at the school of Ingenieros de Caminos, Canales y Puertos of the Universidad Politécnica de Madrid, is presented. Undergraduate students have visited two high schools to present their Final Degree Projects (civil engineering curriculum) to the high school students. Three kind of reviews have been recollected: the review of the faculty advisors, the (peer) review among the undergraduate students and the review of the high school students. This experience have shown the usefulness of peer-review among students and the strength of service learning activities to improve the motivation and the learning process.
\end{abstract}

Keywords: Service-learning, motivation, school dropout, student recruitment.

\section{INTRODUCTION}

Service-learning (S-L) is defined as the process of learning by doing a community service to society [1]. There are many examples in the bibliography that prove that the S-L promotes not only transversal competences of the curriculum but also values, skills and social attitudes that will be very useful for the professional and personal development of the students and future professionals. At the same time, S-L improves the motivation of the students, developing their sense of self-reliance and self-esteem [2] [3].

Following the S-L approach, in this work we wanted to implement activities to support secondary education, specifically by improving the motivation of young students and reducing the rate of school dropout. The School of Civil Engineering of Madrid (E.T.S de Ingenieros de Caminos, Canales y Puertos, U.P.M.) has established agreements with high schools institutes in the Autonomous Government of Madrid so university students present their Final Degree Project to high school students in special shared sessions. The scope of the project has two simultaneous and complementary learning lines:

a) university students will strengthen skills such as creativity, oral presentation, information management... and, at the same time, will increase their self-reliance as they have to adopt the role of educator in front of the high school students, and

b) High school students will see, from university students with ages very close to theirs, the display of a civil engineering project, which will bolster their interest in engineering and technology and will contribute to a motivation increase in pursuing university education (reducing the rates of school dropouts).

In order to develop this project and achieve the desired goals, final degree projects of the Civil Engineering Curriculum (roads, dams, ports, bridges...) were selected and presented by their studentauthors in two high schools in Madrid. The main achieved objective was support for education, for both high school students and university students, through Learning-Service methodology. Secondary objectives were the promotion of civil engineering studies among high school students and the establishment of relationships between the School of Civil Engineering (U.P.M.) and secondary schools that may allow future collaborations.

\section{METHODOLOGY}

This study was performed by gathering the needs of two types of institutions and, therefore, focused in two types of students. That is to say, high school and university students were linked. In order to do so, lecturers from E.T.S de Ingenieros de Caminos, Canales y Puertos (ETSICCP) at Universidad 
Politécnica de Madrid (UPM) met teachers from two high schools: I.E.S Gerardo Diego (Pozuelo-Madrid) and Liceo Villafontana (Móstololes-Madrid). The institutions that held the interchange were chosen from those most relevant in the Madrid region.

Two parallel works were developed by the university lecturers in order to accomplish the main objectives: find students doing their final projects in Civil Engineering that volunteered to perform such an experience and contact high-school teachers and institutions that found interesting the project. Once this was achieved, all of them were informed of the procedure to follow and a date was fixed for the presentation of the students.

The students prepared a preliminary presentation that was reviewed by both their final project supervisors and the team of lecturers of the project. The main aims of this review were helping the students in focusing their speech to the type of audience they were going to have and choosing the best content of the projects for each institution given that they were not performed in the same academic subjects.

The teachers at high-school institutions also made a previous works that were varied depending on the subject. The main goal was to transmit what an engineering project is and the various concepts that are involved in the Civil Engineering field.

Finally, each of the seven university students made a presentation for a classroom of high school ranging 15-25 students and between 12 and 15 years old. Each presentation lasted 15 minutes and additional time-periods of 10 minutes were used to answer questions of the high-school students. After the presentation, the students filled the evaluation rubric (see appendix A) in order to measure the interest of this project. All presentations were recorded in video and sent to the other undergraduate students (peer-review) and the students' university advisors to obtain also evaluation rubrics of these participants.

\section{RESULTS}

Ten lectures have been given at the two high schools, presented by seven undergraduate students, to 152 high school students in three different days. Around $82 \%$ of these high school students liked the activity and around a $77 \%$ of them got a better understanding of the professional activities of a Civil Engineer.

If we narrow our attention to the three main outcomes the evaluation rubric asks for, i.e. "Technical content", "Presentation Skills and Composition" and "Design", we obtain the results summarised in Figures 1, 2 and 3. In this figures label A stands for "Excellent: belongs to the top 10\%", B stands for "Satisfactory: reaches the requirements" and C stands for "Unsatisfactory: does not reach the minimum requirements"

In these figures we can see the ratios of $A, B$ and $C$ evaluations given by the high school students (left), by the faculty advisor (center) and by the other undergraduate students (right) for only one of the ten undergraduate presentations. Although the evaluations of the presentations show some variability, all of them have a similar pattern and only one is presented in this work.

We can see from these figures that the faculty advisor reviews give the better marks, being the peerreview between the undergraduate students less positive. Surprisingly, high student reviews have given the lowest marks. 


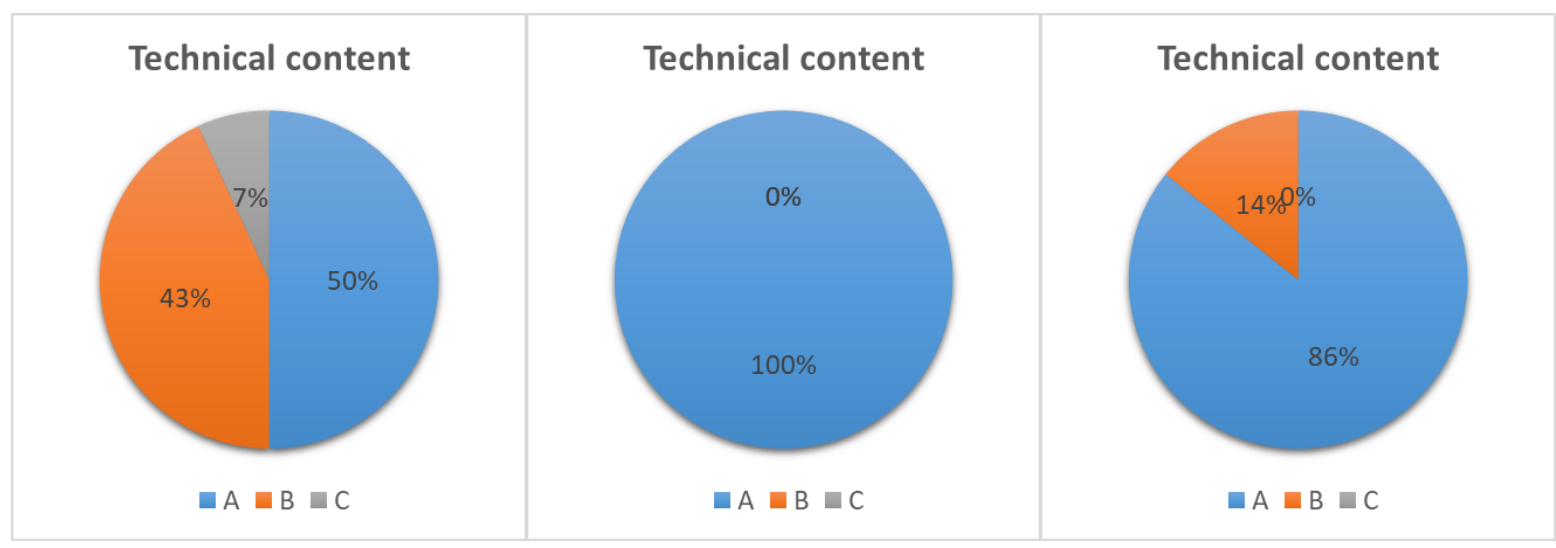

High school students

Faculty Advisor

Undergraduate Students

Figure 1. Results for outcome "Technical content"

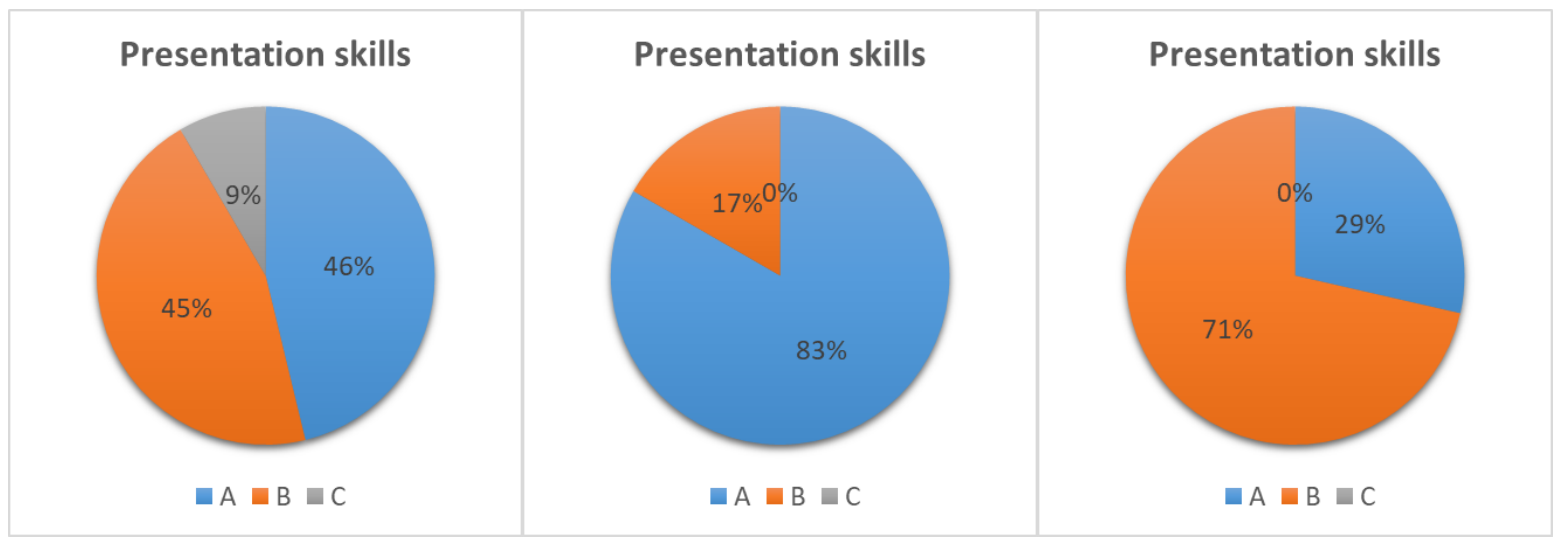

High school students

Faculty Advisor

Undergraduate Students

Figure 2. Results for outcome "Presentation skills" 


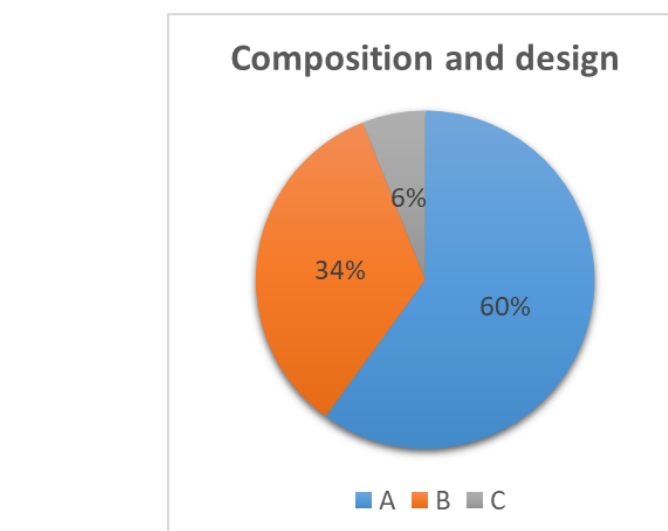

\section{Composition and design}
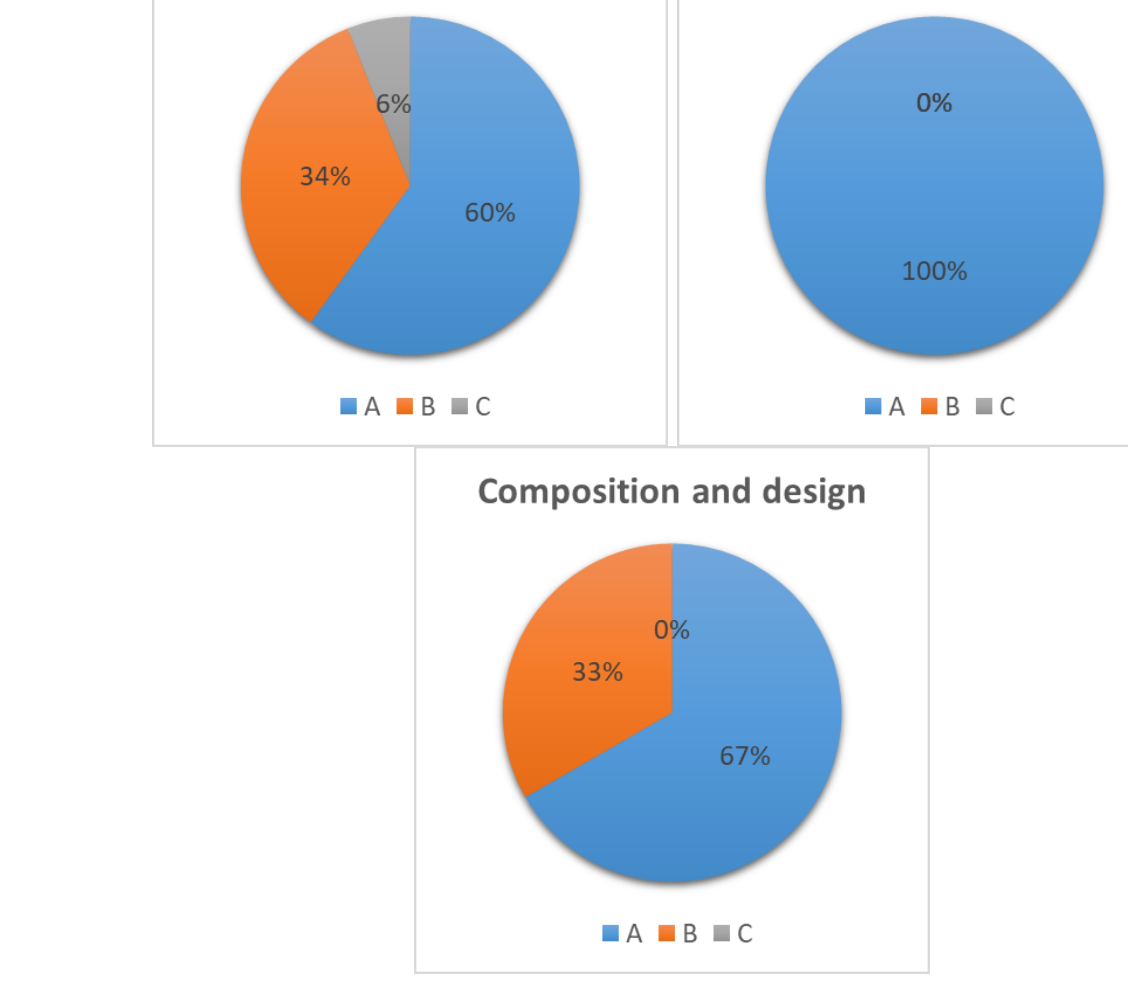

High school students

Faculty Advisor

Undergraduate Students

Figure 3. Results for outcome "Composition and design"

\section{CONCLUSIONS}

Undergraduate students need accurate feedback from their work, in order to properly assess their actual level of acquisition of competences. Unfortunately, they do not receive as much feedback as needed from the faculty instructors, especially in case the number of students per course is too large. Peerreview offers a valuable tool to allow this feedback and to encourage the process of learning. Moreover, the context provided by the service-learning activity provides an appealing environment where students' motivation is boosted and the learning process promoted.

\section{ACKNOWLEDGEMENTS}

This work has been supported by Universidad Politécnica de Madrid under Projects No IE1718.0414. The authors wish to thank the collaborations of I.E.S Gerardo Diego (Pozuelo-Madrid) and Liceo Villafontana (Móstololes-Madrid).

\section{APPENDIX A}

\begin{tabular}{|l|l|l|l|}
\hline Criteria & $\begin{array}{l}\text { Unsatisfactory: does not } \\
\text { reach the minimum } \\
\text { requirements }\end{array}$ & $\begin{array}{l}\text { Satisfactory: reaches } \\
\text { the requirements }\end{array}$ & $\begin{array}{l}\text { Excellent: belongs to } \\
\text { the top } 10 \%\end{array}$ \\
\hline $\begin{array}{l}\text { Technical } \\
\text { content }\end{array}$ & (C) Unsatisfactory & (B) Satisfactory & (A) Excellent \\
\hline
\end{tabular}




\begin{tabular}{|c|c|c|c|}
\hline & $\begin{array}{l}\text { The work presented is not } \\
\text { at the level of a } \\
\text { professional work, being } \\
\text { deficient in terms of } \\
\text { reliability and } \\
\text { completeness }\end{array}$ & $\begin{array}{l}\text { The work presented } \\
\text { boosts the level of a } \\
\text { professional work }\end{array}$ & $\begin{array}{l}\text { The technical level of the } \\
\text { work presented is } \\
\text { excellent and would even } \\
\text { be an outstanding solution } \\
\text { in a professional } \\
\text { environment }\end{array}$ \\
\hline & $\begin{array}{l}\text { I did not understand the } \\
\text { project properly and I } \\
\text { would not be able to } \\
\text { explain it to another } \\
\text { partner }\end{array}$ & $\begin{array}{l}\text { I understood the project } \\
\text { properly and I would be } \\
\text { able to explain the main } \\
\text { ideas to another partner }\end{array}$ & $\begin{array}{l}\text { I perfectly understood the } \\
\text { project and I would be } \\
\text { able to explain it in detail } \\
\text { to another partner }\end{array}$ \\
\hline & $\begin{array}{l}\text { It is not clear to me what } \\
\text { was the problem to be } \\
\text { solved in the project }\end{array}$ & $\begin{array}{l}\text { The problem to be solved } \\
\text { by the project is clear to } \\
\text { me and I would be able to } \\
\text { express it }\end{array}$ & $\begin{array}{l}\text { The problem to be solved } \\
\text { by the project is clear to } \\
\text { me and I would be able to } \\
\text { identify analogous } \\
\text { situations where the same } \\
\text { solution could be applied }\end{array}$ \\
\hline & $\begin{array}{l}\text { It is not clear to me what } \\
\text { restrictions, laws or } \\
\text { approaches may limit the } \\
\text { proposed solution }\end{array}$ & $\begin{array}{l}\text { I understand the } \\
\text { restrictions, laws or } \\
\text { approaches that the } \\
\text { project should meet in } \\
\text { order to consider it } \\
\text { feasible }\end{array}$ & $\begin{array}{l}\text { I understand the } \\
\text { requirements that the } \\
\text { project should meet and I } \\
\text { could propose alternative } \\
\text { examples }\end{array}$ \\
\hline & $\begin{array}{l}\text { I have the feeling that the } \\
\text { most relevant parts of the } \\
\text { project have not been } \\
\text { explained }\end{array}$ & $\begin{array}{l}\text { I feel that all the relevant } \\
\text { parts of the project have } \\
\text { been explained }\end{array}$ & $\begin{array}{l}\text { I understood all the } \\
\text { relevant aspects of the } \\
\text { project and I could count } \\
\text { them in detail }\end{array}$ \\
\hline & $\begin{array}{l}\text { Our questions have been } \\
\text { inadequately answered }\end{array}$ & $\begin{array}{l}\text { Our questions have been } \\
\text { adequately answered }\end{array}$ & $\begin{array}{l}\text { Our questions have been } \\
\text { clearly answered and I } \\
\text { would like to know more } \\
\text { about the project }\end{array}$ \\
\hline & $\begin{array}{l}\text { I think the critics have } \\
\text { been answered } \\
\text { inadequately }\end{array}$ & $\begin{array}{l}\text { I think the critics have } \\
\text { been answered } \\
\text { adequately }\end{array}$ & $\begin{array}{l}\text { The critic have been } \\
\text { clarified and an effort was } \\
\text { made to help me } \\
\text { understanding them, } \\
\text { defending the point of } \\
\text { view and recognising } \\
\text { possible improvements }\end{array}$ \\
\hline Criteria & $\begin{array}{l}\text { Unsatisfactory: does not } \\
\text { reach the minimum } \\
\text { requirements }\end{array}$ & $\begin{array}{l}\text { Satisfactory: reaches } \\
\text { the requirements }\end{array}$ & $\begin{array}{l}\text { Excellent: belongs to } \\
\text { the top } 10 \%\end{array}$ \\
\hline \multirow[t]{2}{*}{$\begin{array}{l}\text { Presentation } \\
\text { skills }\end{array}$} & (C) Unsatisfactory & (B) Satisfactory & (A) Excellent \\
\hline & $\begin{array}{l}\text { He barely looked to the } \\
\text { audience and it seems like } \\
\text { if he would not be } \\
\text { speaking to me (looks to } \\
\text { the sheet or a wall) }\end{array}$ & $\begin{array}{l}\text { There was eye-contact } \\
\text { with the audience and it } \\
\text { seems to be speaking to } \\
\text { me during the speech }\end{array}$ & $\begin{array}{l}\text { He captures the audience, } \\
\text { making me feel like part of } \\
\text { a conversation reaching } \\
\text { the complete attention of } \\
\text { the public }\end{array}$ \\
\hline
\end{tabular}




\begin{tabular}{|c|c|c|c|}
\hline & $\begin{array}{l}\text { The body language is } \\
\text { uncomfortable and I } \\
\text { become distracted; it is } \\
\text { not appropriate }\end{array}$ & $\begin{array}{l}\text { The body language was } \\
\text { correct }\end{array}$ & $\begin{array}{l}\text { The body language was } \\
\text { outstanding showing } \\
\text { control and self-assurance }\end{array}$ \\
\hline & $\begin{array}{l}\text { He was not able to } \\
\text { continue when he made a } \\
\text { mistake }\end{array}$ & $\begin{array}{l}\text { Mistakes did not have any } \\
\text { impact on the presentation }\end{array}$ & $\begin{array}{l}\text { He continued unaffectedly } \\
\text { after a mistake }\end{array}$ \\
\hline & $\begin{array}{l}\text { He spoke too fast or too } \\
\text { slow }\end{array}$ & $\begin{array}{l}\text { He speaks at an } \\
\text { acceptable pace, } \\
\text { sometimes a bit fast/slow, } \\
\text { but correct in general }\end{array}$ & $\begin{array}{l}\text { The pace of the speech } \\
\text { was correct during the } \\
\text { whole speech }\end{array}$ \\
\hline & $\begin{array}{l}\text { Some grammatical } \\
\text { mistakes could be } \\
\text { appreciated }\end{array}$ & $\begin{array}{l}\text { No grammatical mistakes } \\
\text { could be appreciated } \\
\text { though the vocabulary } \\
\text { was poor }\end{array}$ & $\begin{array}{l}\text { I was delighted with the } \\
\text { language he used. } \\
\text { Precise sentences helped } \\
\text { me understanding the } \\
\text { concepts }\end{array}$ \\
\hline & $\begin{array}{l}\text { The way of speaking was } \\
\text { boring and I lost the } \\
\text { attention almost from the } \\
\text { beginning }\end{array}$ & $\begin{array}{l}\text { He kept the attention of } \\
\text { the audience, although I } \\
\text { had to make an effort to } \\
\text { follow the presentation }\end{array}$ & $\begin{array}{l}\text { With the way of speaking } \\
\text { he has maintained my } \\
\text { attention without any effort }\end{array}$ \\
\hline & $\begin{array}{l}\text { The presentation was too } \\
\text { difficult (too easy) for the } \\
\text { audience }\end{array}$ & $\begin{array}{l}\text { The presentation was } \\
\text { congruent with the } \\
\text { audience though some } \\
\text { parts were too difficult (too } \\
\text { easy) }\end{array}$ & $\begin{array}{l}\text { The presentation was } \\
\text { perfectly congruent with } \\
\text { the audience }\end{array}$ \\
\hline Criteria & $\begin{array}{l}\text { Unsatisfactory: does not } \\
\text { reach the minimum } \\
\text { requirements }\end{array}$ & $\begin{array}{l}\text { Satisfactory: reaches } \\
\text { the requirements }\end{array}$ & $\begin{array}{l}\text { Excellent: belongs to } \\
\text { the top } 10 \%\end{array}$ \\
\hline \multirow{4}{*}{$\begin{array}{l}\text { Composition } \\
\text { and design }\end{array}$} & (C) Unsatisfactory & (B) Satisfactory & (A) Excellent \\
\hline & $\begin{array}{l}\text { The presentation was to } \\
\text { short/long (less than } 10 \\
\text { minutes or more than } 20 \\
\text { minutes) }\end{array}$ & $\begin{array}{l}\text { The presentation was } \\
\text { adjusted accordingly to its } \\
\text { allotted time }(+/-4 \mathrm{~min})\end{array}$ & $\begin{array}{l}\text { The presentation lasted its } \\
\text { allotted time }\end{array}$ \\
\hline & $\begin{array}{l}\text { The slides were poor: too } \\
\text { much or too low detail, } \\
\text { difficult to understand, } \\
\text { small characters and } \\
\text { figures, messy }\end{array}$ & Adequate slides & $\begin{array}{l}\text { Outstanding slides: clear, } \\
\text { good image, well } \\
\text { structured }\end{array}$ \\
\hline & $\begin{array}{l}\text { The structure of the } \\
\text { presentation was poor } \\
\text { (missing parts, } \\
\text { unintelligible order, I forgot } \\
\text { parts of the presentation) }\end{array}$ & $\begin{array}{l}\text { There was a coherent } \\
\text { order in the presentation } \\
\text { although I miss some } \\
\text { parts of it }\end{array}$ & $\begin{array}{l}\text { There was a very good } \\
\text { order in the presentation. } \\
\text { The sequence of the } \\
\text { structured seemed to be } \\
\text { easy and natural, easy to } \\
\text { follow }\end{array}$ \\
\hline
\end{tabular}




\begin{tabular}{|l|l|l|l|}
\hline Question & Yes & No & $\begin{array}{c}\text { I am not } \\
\text { sure }\end{array}$ \\
\hline $\begin{array}{l}\text { It was easy to answer the evaluation rubric, I had the adequate } \\
\text { answer for each question }\end{array}$ & & & \\
\hline I liked the activity, it was interesting for me & & & \\
\hline $\begin{array}{l}\text { After the presentations I have a better comprehension about the } \\
\text { activities conducted by Civil Engineers }\end{array}$ & & & \\
\hline $\begin{array}{l}\text { I was not planning to study engineering though after the presentation } \\
\text { I am thinking about such possibility }\end{array}$ & & & \\
\hline $\begin{array}{l}\text { I was planning to study engineering though after the presentation } \\
\text { some doubts appeared about doing it }\end{array}$ & & & \\
\hline $\begin{array}{l}\text { I was planning to study engineering and after the presentation I am } \\
\text { willing to do so }\end{array}$ & & & \\
\hline $\begin{array}{l}\text { I was not planning to study engineering and after the presentation I } \\
\text { have not changed my mind }\end{array}$ & & & \\
\hline
\end{tabular}

Write the comment you want about the activity:

\section{REFERENCES}

[1] Eyler, Janet, and Dwight E. Giles Jr. "Where's the Learning in Service-Learning?" Jossey-Bass Higher and Adult Education Series. Jossey-Bass, Inc., 350 Sansome St., San Francisco, CA 94104, 1999.

[2] Waterman, Alan S. "An overview of service-learning and the role of research and evaluation in service-learning programs." Service-learning. Routledge, 2014. 15-26.

[3] Rosenberger, Cynthia. "Beyond empathy: Developing critical consciousness through service learning." Integrating service learning and multicultural education in colleges and universities. Routledge, 2014. 39-60.. 